\title{
What is the Effect of Contemporary Financial Concepts on Business Performances of the Serbian Companies? ${ }^{4}$
}

\author{
Article history: \\ Received: 3 October 2019 \\ Sent for revision: 7 October 2019 \\ Received in revised form: 18 November 2019 \\ Accepted: 19 November 2019 \\ Available online: 31 December 2019
}

\begin{abstract}
The main focus of this paper is the analysis of the implementation of modern financial concepts such as NPV, IRR etc. in everyday business activities of the Serbian companies. The aim of the paper is to establish the link between the implementation of contemporary financial concepts and profitability of the company, quantified by Net profit, using binary logistic regression. The implementation is investigated by surveying the sample of 65 companies and CFOs (chief financial directors) within the period from 2015 till 2018. Two surveys were conveyed within the above-mentioned period. Analysis of the responses of 65 financial executives was conducted within the period from 2015 to 2018. Analysis of profitability indicators of the companies in the sample, acquired from relevant documents such as Balance Sheet, Income Statement, Notes to the Financial Statements and Annual Business Reports, was conducted within the period from 2015 till 2018. The results confirm that well defined investment policy with implementation of the suitable investment criteria positively influences the business performance of companies in Serbia. However, for successful business performances pure technical knowledge is not enough - flexibility and adaptability of managers is gaining the growing importance within changing economic environment.
\end{abstract}

Keywords: Capital Budgeting, Capital Budgeting Techniques, NPV, PP, Profitability, Net Profit.

\footnotetext{
${ }^{1}$ FEFA, Metropolitan University, avjetrov@fefa.edu.rs

${ }^{2}$ Singidunum University, Faculty of Business

${ }^{3}$ University Union Nikola Tesla, Faculty for business studies and law

${ }^{4}$ This Research Paper was the part of the project no. 47028, in the period 2011-2019, financed by the Serbian Ministry of Science and Technological Development.
} 
Vjetrov A. et al.: What is the Effect of Contemporary Financial Concepts on Business...

\title{
Analiza uticaja savremenih finansijskih koncepata na poslovne performanse preduzeća u Srbiji
}

\begin{abstract}
Apstrakt: Glavni fokus ovog rada je analiza primene savremenih finansijskih koncepata kao što su NPV, IRR itd. u svakodnevnim poslovnim aktivnostima preduzeća u Srbiji. Cilj rada je uspostavljanje veze između primene savremenih finansijskih koncepata i profitabilnosti kompanije, kvantifikovane indikatorom neto dobiti, koristeći binarnu logističku regresiju. Sama implementacija je ispitana putem uzorka koji se sastoji od 65 kompanija i upitnika koji su poslati finansijskim direktorima u periodu od 2015. do 2018. godine. Sprovedena su dva istraživanja: analiza odgovora 65 finansijskih direktora u periodu od 2015. do 2018. godine $i$ analiza pokazatelja profitabilnosti kompanija u uzorku, dobijenih iz relevantnih dokumenata poput bilansa stanja, bilansa uspeha, Napomena uz finansijske izveštaje i Godišnjih izveštaja o poslovanju u periodu od 2015. do 2018. godine. Sprovedeno istraživanje potvrđuje da dobro definisana investiciona politika uz primenu odgovarajućih tehnika budžetiranja kapitala, pozitivno utiče na poslovne rezultate kompanija u Srbiji. Međutim, za uspešne poslovne performance čisto tehničko znanje nije dovoljno - fleksibilnost i prilagodljivost menadžera dobija sve veći značaj u promenljivom ekonomskom okruženju.
\end{abstract}

Ključne reči: budžetiranje kapitala, tehnike budžetiranja kapitala, NSV, PP, profitabilnost, neto dobit

\section{Introduction}

Investments represent necessity for the development both on micro and macro level. However, it is important to determine which investments are feasible and profitable and which are not. In order to choose the investment that adds the value to the owners, it is necessary for the companies to have well defined capital budgeting policy, within which they would choose lucrative investments by implementing capital budgeting techniques. The emphasis within the paper is put on the micro level, determining what capital budgeting techniques companies in Serbia frequently use. Contemporary finance theory defines the following investment criteria when deciding about the investing (Dayananda, Irons, Harrison \& Rowland, 2002; Brealey, Myers \& Marcus, 2007; Van Horne \& Wachowicz, 2007; Rosenbaum \& Pearl, 2009; Rose \& Hudgins, 2005; Luigi \& Sorin, 2009; Sarwary, 2019): Net Present Value (NPV), Payback Period (PP), Internal Rate of Return (IRR), Accounting Rate of Return (ARR), Profitability Index (PI) and discounted Payback Period. The main difference between above mentioned investment criteria is that ARR and PP represent NDCF (non - discounted cash flow techniques), i.e. the 
Vjetrov A. et al.: What is the Effect of Contemporary Financial Concepts on Business...

techniques that do not take time value of money into consideration. NPV, IRR, $\mathrm{PI}$ and discounted PP take time value of money into consideration, consequently discounting the CF. However, the problem may occur upon defining the discount rate using various methods - WACC (Weighted Average Cost of Capital), CAPM (Capital Asset Pricing Model), Dividend Discount Model (DDM) etc. due to the various factors such as inefficient capital market, small number of public companies in Serbia, financial illiteracy etc. (Gonenc \& Haan, 2014; Toci \& Hashi, 2010; Barjaktarovic, Djulic, Pindzo \& Vjetrov, 2016; Djulic, Barjaktarovic, Pindzo \& Vjetrov, 2017; Barjaktarovic, Pindzo, Djulic \& Vjetrov, 2017).

The aim of this paper is to show that there is certain connection between well -defined investment policies, which is seen through actual implementation of capital budgeting techniques, with business performance of the company, observed through net profit. The main focus of the paper is to determine which elements of the investment policy defined by the company contribute the most to the profitability of the company, measured by profit. Consequently, $\mathrm{HO}$ hypothesis of the paper is:

H0: Well defined investment policy, with implementation of the suitable investment criteria, positively influences the business performance of the companies in Serbia.

However, in changing economic environment, some personal distinctive features, related to managers making these strategic decisions, appeared to be value per se. Apart from technical knowledge, CFO (Chief Financial Officer) has to possess soft skills as well and the instinct to determine how to adapt its company and its strategy to newly created conditions. Continuity and heliocentric approach is long forgone concept, forcing the successful managers to be adaptable, agile, and open to changes.

This paper is structured as follows. Within the first section the literature review is presented. In the section two, the methodology is presented, including a detailed description of the survey and statistical methods implemented. The third section contains the results of authors' survey. Finally, the conclusion is given in the last section of the paper.

It is important to stress out that this survey is the addition to survey initiated in 2015. In 2018, additional questions were sent to the companies, in order to see if there were some changes that occurred meanwhile and get additional clarifications, if there were some ambiguities. This is thoroughly explained in the methodology section. 
Vjetrov A. et al.: What is the Effect of Contemporary Financial Concepts on Business...

\section{Literature review}

Technology and the innovations, as the crucial part of development on macro and micro level, has been the main subject of various papers and researches, focusing on the importance of entrepreneurship. However, even though the year 2016 was declared as the year of entrepreneurship in Serbia, there are still many restrictions for doing business, especially for micro enterprises (Krstic, Fedajev \& Nikolic, 2018). Investments represent the necessary precondition for enterprises' development and within the context of changing business environment and related risks, the focus should be on proactivity and flexibility. Investments have to be the appropriate instrument for the enterprises to be resilient to uncertainties by adapting themselves continuously to the new conditions (Silvola, 2006; Hornstein, 2011; Benouna, 2010).

These results emphasize the importance of well-defined investment policy and its contribution to the profitability of the company. At the same time, these results helped the authors of this paper in defining $\mathrm{HO}$ hypothesis. Finally, there are two questions to be answered: 1) How to determine which investment increases the value for the owner(s)?; 2) Is there a connection between investments and profitability?

Finance theories emphasize capital budgeting techniques which are used in order to assess the feasibility of investments: 1) discounted cash flow techniques (DCF) and 2) non- discounted cash flow techniques (NDCF). As it is already explained, the main difference between DCF and NDCF is the fact that DCF take into consideration time value of money and the latter do not (Gowthorpe, 2009). DCF techniques are: 1) Net present value (NPV); 2) Internal rate of return (IRR); 3) Profitability index (PI) and 4) Discounted payback period (DPP). NDCF techniques are: 1) Accounting rate of return (ARR) and 2) Payback period (PP) (Chen, 2008). Their implementation in practice was the subject of many researches in the past. For instance, Graham \& Harvey (2001) conveyed the survey in United States of America (USA) and Canada within the period from 1998 to 1999. The survey included 392 chief financial officers (CFOs), that answered the questions within the scale from 1 to 4 (where 1 meant "never" and 4 meant "indicating frequent usage") regarding the topics like cost of capital, capital structure and capital budgeting techniques. The most frequent techniques used by CFOs were: 1) IRR $(75.7 \%)$ and 2) NPV (74.9\%). Other techniques were used in the following order: 1) PP (56.74\%); 2) Sensitivity analysis (51.54\%); 3) DPP (29.45\%); 4) ARR (20.29\%); and 5) PI (11.87\%). The results unambiguously show the dominance of DCF techniques in practice in comparison to NDCF. 
Vjetrov A. et al.: What is the Effect of Contemporary Financial Concepts on Business...

Andor, Mohanty \& Toth (2011) did the similar survey including 400 companies in 10 Central and Eastern European countries (CEE region): Bulgaria, Croatia, Czech Republic, Hungary, Lithuania, Latvia, Poland, Romania, Slovakia and Slovenia. The results indicate that the most frequent investment criteria used in CEE region is PP (66\%) and ARR (60\%). The survey unambiguously show different results in comparison to the results gained in USA, Canada and Western European countries. Here, the dominance of NDCF techniques is evident; especially ARR. DCF techniques are used as follows: 1) NPV (52\%) and 2) IRR (50\%) in the sample consisting of 400 companies in CEE region.

Having tackled the issue of ways of choosing the profitable investments, the next step is to determine the possible link between the investment policy and the profitability of the companies. There were previous surveys examining connection between aggressive working capital management and profitability of US companies. For instance, Jose, Lancaster \& Stevens (1996) examined the connection between aggressive working capital management measured by Cash Conversion Cycle, where shorter cycle represents more aggressive working capital management policy and the profitability. The final conclusion of the survey was that there was a negative connection between Cash Conversion Cycle and profitability of the company, implying that more aggressive working capital policy is connected to higher profitability of the company.

Vineet Kaur \& Singh (2014) performed a survey by using the sample of 164 companies in India, within the period from 2000 to 2010, investigating the relation between working capital investment policy and the profitability of the companies. They measured the degree of aggressiveness related to investment policy, as the ratio of total current assets and total assets, where lower ratio indicates more aggressive investment policy. The profitability of the companies was measured with ROE (Return on Equity) and ROA (Return on Assets). The final conclusion is that the financial managers should design and implement an efficient investment policy in order to manage effectively their working capital and to contribute positively to the creation of the company's value.

Mugurel \& Gabriel (2012) stressed in their research that investments are the main way of improving the activity of firms and boosting all the indicators reflecting the efficiency of the firm. Basu \& Das (2017) established the link between profit and investments by analysing 55 industries in India within the period from 1983 to 1984 and from 2007 to 2008. The results unambiguously show the strong connection between profitability and the level of investments. They also stressed that this link was stronger in manufacturing sector. Their findings indicate, as well, that technological improvements and growth of 
Vjetrov A. et al.: What is the Effect of Contemporary Financial Concepts on Business...

internal finance stimulate the level of the investments in the long run. However, in order to boost investments, well developed financial markets are needed, considering the fact that they have important positive role on economic growth (Bozovic, 2019). The latter was emphasized in the paper, by using ordinary least-squares estimator with robust standard errors and monthly seasonal dummies, where real per capita GDP growth represented dependant variable and lagged GDP per capita, government consumption as a fraction of GDP, foreign direct investments (FDI) as a fraction of GDP, inflation rate, turnover ratio, relative broad money (M3) as a fraction of GDP represented explanatory variables. One of the main conclusions of the analysis is that the liquidity of the stock market is positively correlated with economic growth.

\section{Research Methodology}

The survey was conveyed in Serbia within the period from 2015 to 2018. Questionnaires were sent to 392 mail addresses, and the overall number of CFOs that responded was 65 . The survey was first initiated in the period from 2015 to 2017 . However, survey was repeated in 2018 in order to see if there were some changes and for additional clarifications in case of certain ambiguities. The questionnaire contained nine questions regarding the capital budgeting, capital budgeting techniques, cost of capital and discount rate. Respondents were given the option to answer to each question within the range from 1-5 (1-never; 2-seldom; 3-sometimes; 4-often; 5-always). However, in case of some ambiguities, the respondents were contacted by authors, in order to clarify the uncertainty.

Survey conveyed by Graham et al. (2001) was used as the starting point for making the questionnaire. The sample comprises 65 companies equally distributed across following industries: trade - $22 \%$; tourism and hospitality $20 \%$; manufacturing and financial sector - $17 \%$ respectively; food industry $12 \%$; IT and agriculture - $5 \%$ respectively; pharmacy and medicine - $2 \%$.

Regarding the size of the companies, the structure of the sample is the following: micro - 23\%, small - 22\%; middle sized - $19 \%$ and large - $36 \%$ (as defined by the Law on Accounting, The Official Gazette of Republic of Serbia no. $62 / 2013,30 / 2018)$. When analysing the capital, $56.9 \%$ of the sample were domestic companies, while $43.1 \%$ were foreign-owned companies. Regarding the revenues, $23 \%$ of the companies had the revenues (average within the period from 2015 to 2018) lower than 82.7 million RSD; $19 \%$ generated the revenue higher than 1.05 billion dinars and lower than 4.2 billion $\mathrm{RSD} ; 36 \%$ of the companies achieved revenues higher than 4.138 billion RSD. Finally, having into consideration net profit as the main indicator, $78 \%$ achieved net 
Vjetrov A. et al.: What is the Effect of Contemporary Financial Concepts on Business...

profit (average within the period from 2015 till 2018) and 22\% incurred net loss. Analysing the type of the company, 23\% enterprises were listed on Belgrade Stock Exchange (BELEX) and $87 \%$ represented limited companies.

Finally, one more addition to the prior research initiated in 2015 was the analysis of the financial reports of the companies within the sample. This was not the subject of the analysis in the prior researches published in various articles. The initial survey was modified in 2018 , by sending the questionnaires to the companies again, in order to perceive if any changes have occurred and by adding the financial report analysis. The main difference between this survey and the prior one is the fact that answers from the questioners were compared with the financial indicators taken from the financial reports of the companies within the period from 2015 till 2018: 1) profitability indicators: revenues, net profit, EBIT (earnings before interest and tax), ROE (return on equity) and 2) solvency and liquidity indicators: current liabilities, long-term liabilities and equity. All data were taken from the documents such as: Income Statement, Balance Sheet, Statement of Cash Flows, Statement of Change in Equity, Annual Reports retrieved from the publicly available data base Business Registers Agency. The second relevant difference is that, in this survey, apart from descriptive statistics, the following statistical methods are used 1) Chi square independency test and 2) Binary logistic regression. In the end, all the data were processed in SPSS program.

\section{Result and discussion}

In order to confirm the hypothesis $\mathrm{HO}$ stating that well defined investment policy with implementation of the suitable investment criteria positively influences the business performance of the companies in Serbia, first, the level of presence of the well- defined investment policy in the companies from the sample should be observed. The respondents answered the question "Does the well-defined investment policy exist in the company you work for?" providing the CFOs with multiple choice answers: 1-never; 2-seldom; 3sometimes; 4-often; 5-always. The answers are presented in Figure 1.

In order to confirm the $\mathrm{HO}$ hypothesis, the necessary precondition is the existence of investment policy in the companies. As it can be seen in Figure 1 , the majority of respondents answered that their company has well - defined investment policy (58\%-always and $32 \%$-often), while only $2 \%$ said "never". However, the answers of the CFOs do not imply its actual realization. It is important to determine which indicators define actual implementation of welldefined investment policy in the company. The next question was related to projection of cash flows i.e., CFOs replied to the question "Do you project cash flow before making investment decision?", where $90 \%$ of the 
Vjetrov A. et al.: What is the Effect of Contemporary Financial Concepts on Business...

respondents answered "always". Projection of cash flows is necessary precondition for implementing investment criteria such as NPV, PP etc., when assessing the investment and its feasibility. The research question was: "How often do you use the following criteria when assessing the investment and its feasibility?". The results are presented in Figure 2.

Figure 1.The investment policy in the companies from the sample (\%)

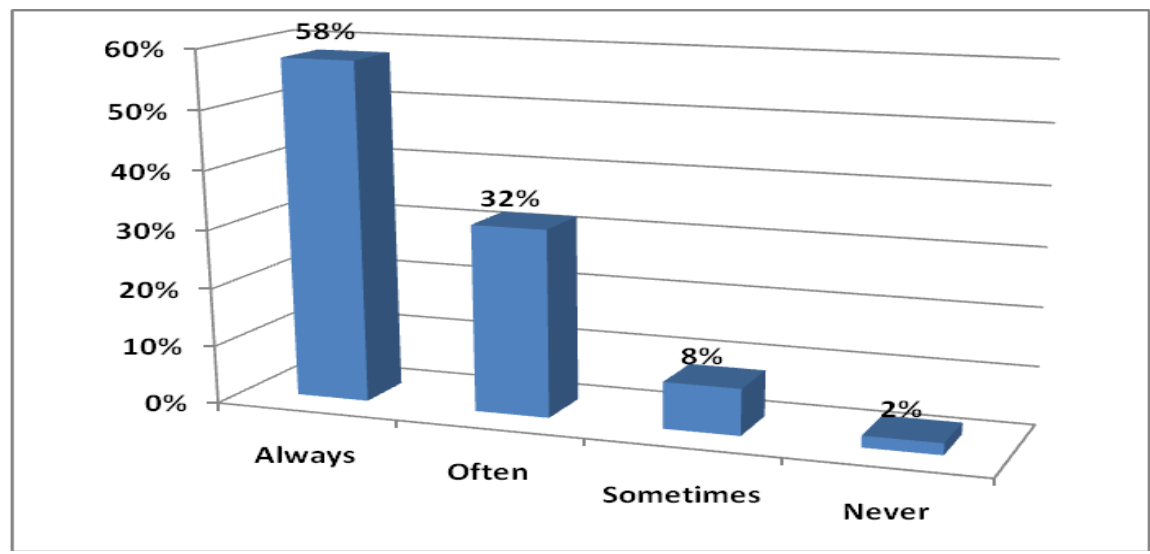

Source: Authors' survey

Figure 2. The implementation of investment criteria in the companies from the sample (\%)

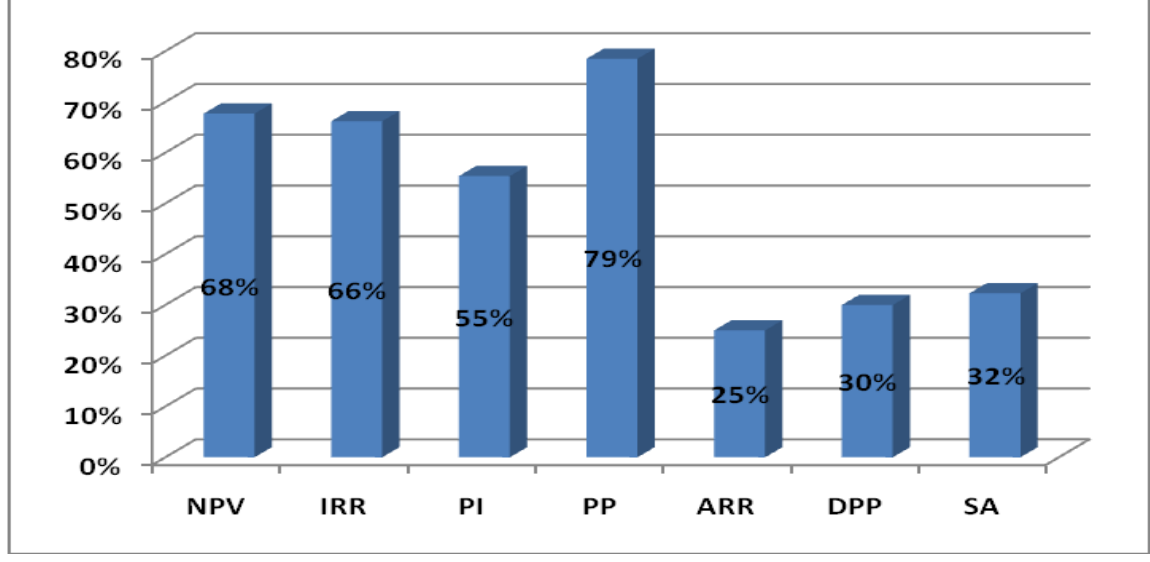

Source: Authors' survey 
Vjetrov A. et al.: What is the Effect of Contemporary Financial Concepts on Business...

Two investment criteria most frequently used in Serbia are PP (79\%) and NPV $(68 \%)$. The results coincide with the previous results. For instance, the survey done in CEE region (Andor et al., 2011), also implies that the most dominant capital budgeting technique is PP, the NDCF technique, i.e. the criteria which does not take into consideration time value of money. The poor developed stock exchange, small number of public companies within the sample and difficulty regarding determining the cost of capital present the obstacles when using DCF techniques in capital budgeting process- indicating the problem in calculating the discount rate, necessary for using criteria like NPV, PI etc. However, even though NPV is not the most frequently used technique, it represents the dominant criteria implemented by CFOs, especially in large companies (75\%) and companies where foreign capital dominates $(76 \%)$.

In order to confirm $\mathrm{HO}$ hypothesis, it is necessary to define the indicators that quantify the success of business performance of the companies within the sample. The following indicators were chosen: ROE and Net profit. Then, it is crucial to determine which capital budgeting technique - NPV or PP better defines the successful implementation of investment policy and their correlation with ROE and Net profit. Thus, Chi square independency, non parametric test is used. First, numeric variables Net profit and ROE are transformed into dichotomous variable: 1) 0 for the companies that incurred average net loss in the period between 2013 and 2017 and 1 for the companies with net profit within the above-mentioned period and 2) 0 for the companies having average ROE lower than $1 \%$ and 1 for the companies having average ROE higher that $1 \%$. Categorical ordinal variables from 1-5 were also transformed into dichotomous variables: 1 ) answers from 1-3 were transformed into 0-rare usage of, for instance, investment technique NPV and 2) answers 4 and 5 were transformed into 1 -frequent usage.

The test showed that there was the connection between investment technique NPV and indicator Net Profit. The research question was: "Is there any association between the implementation of NPV investment technique and the performance of the company quantified by Net Profit and ROE?".

The results are: 1) $\times 2(1,65)=4.206, p$-value $=0.04$ and $p h i=0.293$, indicating significant association between NPV and Net profit (minimum expected cell frequency has not been violated) and 2) $\times 2(1,65)=20.03, p$-value $=0.000$ and phi $=0.59$, statistically significant association, with higher phi coefficient. However, there is no statistically significant association between PP as the investment criteria technique and Net Profit and ROE (performance indicator: 1) $x 2(1,65)=2.069 p$-value $=0.150$, phi $=0.222$ and 2$) \times 2(1,65)=0.952 p$ value $=0.329$, phi $=0.160$. 
Vjetrov A. et al.: What is the Effect of Contemporary Financial Concepts on Business...

The following predictor variables were used in order to test $\mathrm{HO}$ hypothesis using logistic regression: Inv_policy, Projection_CF, and NPV. The variables represent the answers to the following questions: Inv_policy - "Does the welldefined investment policy exist in the company you work for?"; Projection_CF"Do you make CF projections before making investment decision?" and NPV"How often do you use the following criteria when assessing the investment and its feasibility?" These variables were used to quantify the successfulness of investment policy implementation in the company: 1) Its existence and its actual implementation in everyday business life and 2) The implementation of investment criteria within capital budgeting and projection of cash flows, which is necessary precondition for using capital budgeting techniques. The dependent variable within the model is Net profit/loss, depicting the successfulness of business performance of the company. All the variables were transformed into dichotomous variables: 1) Categorical variables Inv_policy, Projection_CF and NPV - answers from 1-3 were transformed into 0 - rare usage and the answers 4 and 5 were transformed into 1-frequent usage 2) Continuous dependent variable Net profit was transformed into 1 (companies gaining net profit) and 0 ( companies incurring net loss). The research question was: "Does well-defined investment policy with implementation of the suitable investment criteria positively influence the business performance of the companies in Serbia?"

All the assumptions hold true for the data regarding the size of the sample, no multicollinearity between independent variables, dependent variable is binary; the observations are independent of each other. Finally, the logistic regression does not make many of the key assumptions of linear regression and general linear models that are based on ordinary least squares algorithms - particularly regarding linearity, normality, homoscedasticity, and measurement level, which makes its usage easier in comparison to other models. The results of binary logistic regression are presented on the following table.

Table 1 The results of binary logistic regression

\begin{tabular}{|l|c|c|c|c|c|}
\hline \multicolumn{1}{|c|}{ Predictors } & B & Wald & df & $p$ & Odds Ratio \\
\hline NPV & 1.895 & 5.794 & 1 & .016 & 6.649 \\
\hline Inv_policy & 1.775 & 2.557 & 1 & .110 & 5.898 \\
\hline Projection_CF & 2.281 & 4.056 & 1 & .044 & 9.786 \\
\hline Constant & -3.446 & 4.696 & 1 & .030 & .032 \\
\hline
\end{tabular}

Source: Authors' survey 
Vjetrov A. et al.: What is the Effect of Contemporary Financial Concepts on Business...

The model contained three independent variables: Inv_policy, Projection_CF and NPV and dependent variable Net profit. The full model is statistically significant - $\mathrm{X} 2(\mathrm{df}=3, \mathrm{n}=54)=12,677, \mathrm{p}<0.05$ (goodness of fit test - Omnibus Tests of Model Coefficients). Hosmer-Lemeshow Goodness of Fit Test indicates that its significance is higher than $0.05(0.642)$, showing also that the model is good. The model as a whole is explained between $20.9 \%$ (Cox \& Snell R square) and $31.3 \%$ (Nagelkerke R square) of the variance of the dependent variable related to profitability. Wald test showed that two out of three predictors are statistically significant (NPV and Projection_CF), with high odds ratio - (6.649 and 9.786, respectively). For instance, odds ratio for NPV is 6.649, indicating that the companies that implement NPV as investment criterion are over 6 times more likely to gain profit in comparison to the companies that do not use NPV. Also, the probability regarding the company's profit is almost 10 times bigger for the companies that project cash flows when analysing investment in comparison to the companies that do not project cash flows.

Finally, the indicator Inv_policy is not statistically significant. However, the odds ratio is positive, indicating that there is higher probability for the companies that have well defined investment policy to be more profitable than the companies that do not have investment policy. There is enough data to confirm $\mathrm{HO}$ hypothesis stating that well defined investment policy with implementation of the suitable investment criteria positively influences the business performance of the companies in Serbia. The clarity and implementation of the investment policy is mostly seen through implementation of investment criteria and projection of CF-necessary precondition for capital budgeting techniques implementation. The answers regarding the existence of well - defined Investment policy have not turned out to be statistically significant. However, elements like investments criteria and projection of CF appeared to be positively correlated with business performance indicator - Net profit.

\section{Conclusion}

The aim of this paper is to perceive the level of dependence between the implementation of financial concepts by the Serbian companies and its influence on business performance of the enterprises within the sample. As it is already stated, the Serbian companies prefer using more traditional methods such as PP in comparison to NPV. However, the results showed that when they use NPV- the method which contemporary finance literature stresses as the most commonly used and recommended method, this is in relation to better business performance of the companies. For instance, the results of Chi square independency, non - parametric test pointed out that 
Vjetrov A. et al.: What is the Effect of Contemporary Financial Concepts on Business...

there was statistically significant link between NPV and Net profit. Consequently, NPV indicator was chosen in order to confirm HO hypothesis but not PP, because there was no statistically significant link between PP and Net profit. Logistic binary regression was used in order to confirm the main hypothesis of the paper. Within the model, predictors were the following variables: NPV, Inv_policy and Projection_CF and the dependent variable was Net profit. The results showed that two of three predictors were statistically significant with high odds ratios, indicating the link between projection of CF and implementation of NPV as important elements of welldefined investment policy and the indicator Net profit as dependent variable, confirming $\mathrm{HO}$ hypothesis of the paper. The results of the analysis emphasized that, even though in the context of unstable business environment with inefficient financial markets, the actual usage and implementation of contemporary concepts such as CF projections and NPV implementation, may lead to better business performance results.

However, it is important to stress out, that within the conditions of constant turmoil, technical skills are important but not crucial for good investments. The ability of managers to be in position to create innovative solutions by using technological advantages of $21^{\text {st }}$ century and not to be resilient to changing environment and risks is important. Constant change and flexibility represent the imperative. This intrinsic instinct in combination with technical knowledge and education of managers ensures better business performances for companies.

The topic of the paper possesses a potential for further investigation. In future, authors of the paper plan to expand the research on the regional level, making the comparative analysis between the Serbian companies and the companies in Slovenia, Croatia, Bosnia and Herzegovina, Montenegro, Macedonia and Albania.

\section{References}

Andor, G., Mohanty, S., \& Toth, T. (2011). Capital budgeting practices: A survey of Central and Eastern European firms. World Bank Review, 1-45.

Barjaktarovic, L, Pindzo, R, Djulic, K., \& Vjetrov, A. (2017). Implementation of ERM concept in Serbia: Comparative analysis - real sector and financial sector. Bankarstvo, 46(2), 51-67.

Barjaktarovic, L., Djulic, K., Pindzo, R., \& Vjetrov, A. (2016). Analysis of the capital budgeting practices: Serbian case. Management: Journal of Sustainable Business And Management Solutions In Emerging Economies, 21(79), 47-54.

Basu D., \& Das, D. (2017). Profitability and investment: evidence from India's organized manufacturing sector. Metroeconomica, 68(1), 47-90. 
Vjetrov A. et al.: What is the Effect of Contemporary Financial Concepts on Business...

Bennouna, K., Meredith, G., \& Marchant, T. (2010). Improved capital budgeting decision making: evidence from Canada. Management Decision, 48(2), 225-247.

Bozovic, M. (2019). Financial development and growth: Evidence from Serbia. Industrija, 47(1), 77-88.

Brealey, R., Myers, S., \& Marcus, A. (2007). Fundamentals of Corporate Finance (5th edition). New York: McGraw-Hill.

Chen, S. (2008). DCF techniques and nonfinancial measures in capital budgeting: A contingency approach analysis. Behavioral Research in Accounting, 20(1), 13-29.

Dayananda, D., Irons, R., Harrison, S., Herbohn, J., \& Rowland, P. (2002). Financial Appraisal of Investment Projects. Cambridge: Cambridge University Press.

Djulic, K., Barjaktarovic, L., Pindzo, R., \& Vjetrov, A., (2017). Analysis of the capital structure decisions: a survey on Serbian companies. Ekonomika preduzeca, 5-6, $355-364$

Gonenc, H., \& Haan, D. (2014). Firm internationalization and capital structure in developing countries: The role of financial development. Emerging Markets Finance \& Trade, 50(2), 169-189.

Gowthorpe, C. (2009). Management Accounting. Belgrade: Data Status.

Graham, J., \& Harvey, C., (2001). The theory and practice of corporate finance: evidence from the field. Journal of Financial Economics, 60, 187-243.

Hornstein, A., \& Zhao, M. (2011). Corporate capital budgeting decisions and information sharing. Journal of Economics \& Management Strategy, 20(4), pp. 1135-1170

Jose, M., Lancaster, M., \& Stevens J. (1996). Corporate returns and cash conversion cycle. Journal of Economics and Finance, 20(1), 33-46.

Krstic, S., Fedajev, A., \& Nikolic, R. (2018). Some aspects of business operations of Serbian economy in 2017. Industrija, 46(4), pp.185-206.

Law on accounting (The Official Gazette of Republic of Serbia no. 62/2013, 30/2018)

Law on auditing (The Official Gazette of Republic of Serbia no. 62/2013, 30/2018)

Luigi P., \& Sorin V. (2009). A review of the capital structure theories. Annals of Faculty of Economics, 3(1), 315-320.

Mugurel, P., \& Gabriel, S. (2012). Influence of the investment decisions on the return of the company. Annals of the University of Oradea: Economic Science Series, 21(2), 302-307.

Pallant, J. (2017). SPSS priručnik za preživljavanje. Belgrade: Mikroknjiga.

Rosenbaum, J., \& Pearl J. (2009). Investment banking: Valuation, leveraged buyouts, and mergers and acquisitions. Hoboken, NJ: John Wiley \& Sons.

Rose, P., \& Hudgins, S. (2005). Bank management \& financial services. Belgrade: Data Status.

Sarwary, Z. (2019). Capital budgeting techniques in SMEs: A literature review. Journal of Accounting and Finance, 19(3), 97-114.

Silvola, H. (2006). Capital Budgeting Methods, Management Control Systems and the R\&D Intensity of the Firm. International Journal of Accounting and Finance, 1(2), 168-92.

Toci, V., \& Hashi I. (2010). Financing constraints, credit rationing and financing obstacles: evidence from firm level data in South-Eastern Europe. Economic and Business Review, 12(1), 29-60.

Van Horne, J., \& Wachowicz J. (2007). Basics of financial management. Belgrade: Data Status. 
Vjetrov A. et al.: What is the Effect of Contemporary Financial Concepts on Business...

VineetKaur, H., \& Singh, S. (2014). Impact of investment and financing policies on profitability and risk. Advances in Business-Related Scientific Research Journal (ABSRJ), 5(2), 183-197. 